\title{
Penyebab Sengketa Pengadaan Tanah untuk Kepentingan Umum \\ (Studi Kasus Sengketa Pengadaan Tanah untuk Kepentingan Umum di Bengkulu)
}

\author{
Yanto Sufriadi \\ Fakultas Hukum Universitas Hazairin Bengkulu \\ Jl. Jenderal Ahmad Yani No. 1 Bengkulu \\ yanto_sufriadi@yahoo.co.id
}

\begin{abstract}
This research focuses on the causes of disputes use for land procurenment used for public importence occurring frequently in the past time how the position of traditional law in the legal substance of national land affairs is how the working procedures of the Land Procurenment Committee (legal structure) are, and how the legal culture of the internal land procurenment executor. This research uses the sociolegal approach and it also uses the data collected from the results of the field study and literature materials. This study concludes that the disputes in land procurenment used for public importance are caused by the centralis substance of the agrarian law, the legal structure of land procurenment executor regulated by the stric formal procedures, and the legal culture of the eecitive apparatus bound by the tradition of legal positivism throught.
\end{abstract}

Key words : Land procurenment used for public importance, disputes, legal system.

\begin{abstract}
Abstrak
Penelitian ini difokuskan pada sengketa pengadaan tanah untuk kepentingan umum yang banyak terjadi di masa lalu : bagaimana kedudukan hukum adat dalam substansi hukum pertanahan nasional, bagaimanakah prosedur kerja Panitia Pengadaan Tanah (struktur hukum), dan bagaimanakah budaya hukum internal pelaksana pengadaan tanah. Penelitian ini menggunakan pendekatan socio legal approach, menggunakan data hasil studi lapangan dan kepustakaan. Studi menyimpulkan bahwa sengketa pengadaan tanah untuk kepentingan umum, disebabkan oleh substansi UUPA yang sentralistik, struktur hukum pelaksana pengadaan tanah yang diatur dengan prosedur formal yang ketat dan budaya hukum aparat pelaksana yang terkekang oleh tradisi berpikir positivisme hukum.
\end{abstract}

Kata kunci : Pengadaan tanah untuk kepentingan umum, sengketa, sistem hukum. 


\section{Pendahuluan}

Pengadaan tanah untuk kepentingan umum, merupakan salah satu kegiatan yang dilakukan pemerintah berkaitan dengan tugas dan tanggungjawabnya untuk memajukan kesejahteraan umum. Tugas negara yang demikian, menyebabkan Indonesia tergolong sebagai negara kesejahteraan (welfarestaat), ${ }^{1}$ dan dalam rangka tersebut kepada negara diberikan wewenang untuk menguasai tanah. ${ }^{2}$

Dalam Pasal 33 ayat (3) Undang-Undang Dasar Negara Republik Indonesia 1945, disebutkan bahwa bumi, air dan kekayaan alam yang terkandung di dalamnya dikuasai oleh negara dan dipergunakan untuk sebesar-besarnya kemakmuran rakyat. Alasan mengapa bumi dan air dan kekayaan alam yang terkandung di dalamnya itu harus dikuasai oleh negara adalah karena bumi, air dan kekayaan alam yang terkadung di dalamnya itu merupakan pokok-pokok kemakmuran rakyat. ${ }^{3}$

Pengertian penguasaan negara atas bumi, air dan kekayaan alam yang terkandung di dalamnya, terdapat dalam Undang-undang No. 5 Tahun 1960 tentang Peraturan Dasar Pokok-Pokok Agraria, yang lebih dikenal dengan sebutan "Undangundang Pokok Agraria (UUPA)". Dalam UUPA ditentukan bahwa hak menguasai negara tersebut, memberi wewenang kepada negara, diantaranya untuk mengatur dan menyelenggarakan peruntukan, penggunaan, persediaan dan pemeliharaan bumi, air dan ruang angkasa. ${ }^{4}$ Berkaitan dengan kewenangan ini, untuk menyelenggarakan penyediaan tanah bagi berbagai keperluan masyarakat dan negara, pemerintah dapat mencabut hak-hak atas tanah dengan memberikan ganti kerugian yang layak menurut cara yang diatur dengan undang-undang, ${ }^{5}$ apabila upaya melalui cara musyawarah gagal membawa hasil. ${ }^{6}$

${ }^{1}$ Faham negara mengalami perkembangan dari political state, menjadi legal state dan akhirnya welfare state. Ketiga faham tersebut semuanya memanfaatkan kekuasaan yang dimiliki negara sebagai penentu kehendak terhadap aktivitas rakyat yang dikuasainya. Kekuasaan negara pada Polical State dipegang oleh seorang Monarch yang absolute. Pada Legal State kekuasaan negara berada secara mutlak di tangan rakyat dalam pemerintahan liberal yang menguntungkan kaum borjuis. Welfare state muncul sebagai jawaban atas ketimpangan sosial-ekonomi yang terjadi dalam sistem ekonomi liberal. negara turut serta dalam seluruh kegiatan sosial, politik dan ekonomi dengan tujuan akhir menciptakan kesejahteraan umum (bestuurszorg). Lihat Mahfud Marbun, Pokok-Pokok Hukum Administrasi Negara, Liberty, Yogyakarta, 1987, hlm. 42.

${ }^{2}$ Yang dimaksud dengan tanah adalah permukaan bumi. Lihat Pasal 4 UU No. 5 Tahun 1960 tentang Peraturan Dasae Pokok-Pokok Agraria.

${ }^{3}$ Penjelasan Pasal 33 UUD 1945

${ }^{4}$ Pasal 2 Ayat (2) huruf a UU No.5 Tahun 1960 tentang Peraturan Dasar Pokok-Pokok Agraia.

${ }^{5}$ Pasal 18 UU No.5 Tahun 1960

${ }^{6}$ Penjelasan Umum UU No. 20 Tahun 1961 tentang Pencabutan Hak-Hak Atas Tanah dan Benda-Benda Yang Ada Di Atasnya. 
Hak menguasai negara atas tanah, juga memberikan wewenang kepada negara untuk mengatur. Dalam melaksanakan wewenang pengaturan tersebut, hal yang sudah disadari oleh pembentuk UUPA, bahwa hukum tanah yang dibangun itu harus didasarkan pada nilai-nilai yang hidup dalam masyarakat Indonesia sendiri, yaitu hukum adat, Secara teoritik, hukum tanah yang dibangun berdasarkan nilainilai yang hidup dalam masyarakat, ${ }^{7}$ dan pencabutan hak atas tanah oleh negara untuk kepentingan umum harus dilakukan dengan pemberian ganti kerugian yang layak $^{8}$ dan sedapat-dapatnya harus diperoleh melalui musyawarah, ${ }^{9}$ maka pengambilan hak atas tanah untuk kepentingan umum, seharusnya akan diterima dan dipatuhi oleh masyarakat, ${ }^{10}$ sehingga sengketa akan relatif jarang terjadi. Akan tetapi kenyataannya, pengadaan tanah untuk kepentingan umum, ternyata banyak menimbulkan sengketa ${ }^{11}$ antara pemerintah dengan para pemilik tanah. .

Pada masa Orde Baru hingga tahun 2001, tercatat sebanyak 1.497 kasus sengketa, dengan luas lahan yang menjadi obyek sengketa mencapai 1.052.514,37 hektar, dan jumlah anggota masyarakat yang menjadi korban sebanyak 232.177 Kepala Keluarga (KK). ${ }^{12}$ Data lainnya menyebutkan banwa pada akhir 2001 tercatat sebanyak 1.753 kasus sengketa. ${ }^{13}$ Kemudian pada 2007 meningkat menjadi sebanyak 2.810 kasus. ${ }^{14}$ Keadaan yang demikian, mengundang pertanyaan, mengapa sistem hukum pengadaan tanah untuk kepentingan umum menimbulkan banyak sengketa.

\section{Rumusan Masalah}

Berdasarkan uraian di atas, permasalahan yang akan dikaji yaitu: pertama, bagaimakah kedudukan hukum adat dalam UUPA? Kedua, bagaimanakah prosedur

${ }^{7}$ Freiderich Carl Von Savigny, mengatakan bahwa hukum itu bukan hanya dikeluarkan oleh penguasa publik dalam bentuk perundang-undangan, namun hukum adalah jiwa bangsa (Volkgeist). Satjipto Rahardjo, Membedah Hukum Progresif, PT Kompas Media Nusantara, Jakarta, 2006, hlm. 164

${ }^{8}$ Pasal 18 UU No. 5 Tahun 1960

${ }^{9}$ Penjelasan Umum UU No. 20 Tahun 1961

${ }^{10}$ Habermas mengatakan bahwa validitas hukum ditentukan oleh consensus yang dibuat oleh elemen-elemen masyarakat. ia tidak melihat nilai-nilai kemanusiaan yang menjadi acuan validitas hukum itu sebagai nilai-nilai obyektif, karena iitu, maka nilai-nilai itu harus ditemukan melalui consensus bersama. Lihat Reza A.A. Wattimena, Melampani Negara HukumKlasik, Locke-Rousseau-Habermas, Penerbit Kanisius, Yogyakarta, 2007, hlm. xvi-xvii.

${ }^{11}$ Sengketa, menurut Kamus Lengkap Bahasa Indonesia, adalah perselisihan, pertikaian, perkara (dalam pengadilan); sesuatu yang menyebabkan perbedaan pendapat, pertengkaran pendapat, pembantahan.

${ }^{12}$ Jayadi Damanik, Pembaruan Agraria dan Hak Asasi Petani, Lapera Pustaka, Yogyakarta, 2002, hlm. 22-23.

${ }^{13}$ Marya S.W Sumardjono, Tanah Dalam Perspektif Hak Ekonomi Sosial dan Budaya, Penerbit Buku Kompas, Jakarta, 2009, hlm. 111

${ }^{14}$ Badan Pertanahan Nasional RI, REFORMA AGRARIA Mandat Politik, Konstitusi dan Hukum Dalam Rangka Mewujudkan Tanab Untuk Keadilan dan Kesejabteraan Rakyat, 2007, hlm. 1 
kerja dari lembaga (struktur) hukum pengadaan tanah untuk kepentingan umum? Ketiga, bagaimanakah budaya hukum aparat pelaksana pengadaan tanah untuk kepentingan umum?

\section{Tujuan Penelitian}

Studi ini bertujuan untuk mengetahui dan menjelaskan tentang penyebab terjadinya sengketa pengadaan ranah untuk kepentingan umum, dan apa yang perlu dilakukan untuk mencegah atau meminimalisir sengketa pengadaan tanah untuk kepentingan umum di masa depan.

\section{Metode Penelitian}

Metode yang digunakan dalam studi ini adalah socio-legal approach yang bersifat kualitatif. Dengan pendekatan socio-legal approach, studi ini menggunakan dua pendekatan, yaitu pendekatan sosial dan pendekatan yuridis normatif. Pendekatan sosial dipergunakan untuk menganalisis sikap, pandangan dan tindakan aktor dalam praktik pengadaan tanah untuk kepentingan umum. Sedangkan pendekatan yuridis normatif dipergunakan untuk menganalisis norma peraturan perundang-undangan dengan mengacu pada nilai-nilai kesejahteraan dan keadilan dalam masyarakat. Analisis yang dilakukan bersifat kualitatif; yang tidak menekankan pada kuantitas data; melainkan pada kualitasnya. Data primer diperoleh melalui wawancara, sedangkan data skunder diperoleh dengan penelusurani dokumen peraturan perundang-undangan, buku, jurnal hukum, hasil-hasil penelitian dan putusan pengadilan yang relevan untuk menjelaskan permasalahan dalam studi ini.

\section{Hasil Penelitian dan Pembahasan}

\section{UUPA Mengusung Ideologi Sentralistik, Mendesak Hukum Adat}

Kondisi sosial budaya Indonesia sangat plural, bahkan tergolong sebagai negara yang paling heterogen di dunia, karena di negara ini terdapat lebih dari 50 bahasa dan 300 kelompok etnis; yang satu dengan lainya amat berbeda. ${ }^{15}$ Kontjaraningrat,

${ }^{15}$ Eka Darma Putera, Pancasila Identitas dan Modernitas : Tinjuauan Etnis dan Budaya, Cetakan Keenam, PT BPK Gunung Mulia, Jakarta, 1997, hlm. 14 
mengemukakan adanya tiga wujud dari suatu kebudayaan, diantaranya adalah kebudayaan sebagai suatu kompleks ide-ide, gagasan-gagasan, nilai-nilai dan norma-norma. ${ }^{16}$ Heterogenitas budaya yang mewarnai masyarakat Indonesia tersebut, dengan sendirinya akan mengakibatkan rerjadinya heterogenitas hukum, yang menjadi orientasi masyarakat dalam berperilaku, termasuk dalam pengelolaan sumber daya alam.

Heterogenitas di bidang hukum, terlihat dari apa yang dikemukakan oleh Van Vollenhoven bahwa di Indonesia terdapat sembilan belas wilayah hukum adat (rechtsringen), ${ }^{17}$ dan di dalam Penjelasan Pasal 18 UUD 1945 disebutkan bahwa di dalam wilayah Indonesia terdapat 250 Zelfberstuurrende land schappen dan Vilksgemeenschappen, seperti desa, dalam masyarakat Jawa dan Bali, nagari dalam masyarakat Minangkabau, dusun dan marga dalam masyarakat Palembang. Daerah-daerah tersebut mempunyai struktur 'asli' dan dianggap sebagai daerah istimewa. ${ }^{18}$ Ter Haar mengemukakan bahwa masyarakat hukum adat di Indonesia merupakan kesatuan masyarakat yang terbentuk atas dasar kesamaan teritorial (wilayah), geneoalogis (keturunan) dan territorial-geneoalogis (wilayah dan keturunan), sehingga terdapat keragaman bentuk masyarakat adat dari suatu tempat dengan tempat lainnya. ${ }^{19}$

Sebelum negara Indonesia didirikan, keragaman hukum yang hidup dalam masyarakat berkaitan dengan pengelolaan sumber daya alam termasuk tanah, paling tidak memperlihatkan adanya dua konsep, yaitu konsep penguasaan tanah pada zaman kerajaan Jawa tradisional, dan menurut konsep hukum adat. ${ }^{20}$

Pada zaman kerajaan Jawa tradisional, raja merupakan pusat ketatanegaraan, dan dipandang sebagai wakil Tuhan. Dalam tradisi ini raja merupakan satu-satunya pemilik tanah dari seluruh kawasan kerajaan. Para priyayi atau abdi dalem yang bekerja sebagai pembantu raja, diberi gaji berupa sebidang tanah lungguh, yang nanti akan ditarik kembali manakala yang menerimanya meninggal dunia. Penarikan

\footnotetext{
${ }^{16}$ Koentjaraningrat, Kebudayaan, Mentalitet dan Pembangunan, Gramedia, Jakarta, 1974, hlm. 15

${ }^{17}$ Kesembilan belas lingkungan hukum adat tersebut, adalah : 1. Aceh, 2. Gayo, Alas, Batak dan Nias, 3. Minangkabau, Mentawai, 4. Sumatera Selatan, Enggano, 5. Melayu, 6. Bangka Belitung, 7. Kalimantan, 8. Minahasa, 9. Gorontalo, 10. Toraja, 11. Sulawesi utara, 12. Kepulauan Ternate, 13. Maluku, 14. Irian Barat, 15. Kepulauan Timor, 16. Bali, Lombok, 17. Jawa Tengah, Jawa Timur, Madura, 18. Solo, Yogyakarta, dan 19. Jawa Barat. Lihat Ade Saptomo, Hukum dan Kearifan Lokal, Revitalisasi Hukum Adat Nusantara, PT. Gramedia Widiasarana Indonesia, Jakarta, 2010, hlm. 13-14.

${ }^{18}$ Ibid.

${ }^{19}$ Ibid., hlm. 16

${ }^{20}$ Achmad Sodiki, Penataan Kepemilikan Hak Atas Tanah di Daerah Perkebunan Kabupaten Malang, Disertasi, PPs Unair, 1994, hlm. 19
} 
kembali itu dapat mencegah penguasa tanah dari para abdi dalem, yang dikhawatirkan akan memperkokoh kekuasaan mereka dan membahayakan kekuasaan raja. ${ }^{21}$ Para sikep, yakni petani yang secara langsung menguasai dan mengolah tanah, dapat memiliki tanah lewat pemberian raja secara langsung atau lewat para priyayi. Raja sewaktu-waktu dapat memerintahkan seorang lurah untuk menyiapkan tenaga serta sumbangan beras dari para sikep ini. ${ }^{22}$ Hubungan antara raja, priyayi dan sikep adalah hubungan kawula gusti atau patron-client.

Konsep penguasaan tanah berdasarkan hukum adat, yang disebut hak ulayat, yaitu suatu hak masyarakat sebagai suatu kesatuan hukum. Hak ulayat, memberikan hak kepada Persekutuan dan anggota-anggotanya untuk menarik manfaat tanah dan segala yang ada di atas tanah itu, mendirikan tempat kediaman, menggembala ternak, mengumpulkan bahan makanan, berburu dan menangkap ikan. Persekutuan dapat menetapkan tanah untuk kepentingan umum, seperti masjid, kuburan, padang ternak, sekolah, tanah jabatan (bengkok) sebagai hadiah kepada para pembesar masyarakat.

Hak ulayat melarang orang luar persekutuan untuk menarik keuntungan dari tanah ulayat yang mereka kuasai, kecuali dengan izin dan sesudah membayar uang pengakuan (recognitie). Orang luar persekutuan, juga dilarang memiliki tanah perseorangan atas tanah pertanian. ${ }^{23}$ Dalam lingkup hak ulayat, terdapat hak individual atas tanah, yang lahir karena pengusahaan yang terus menerus secara intensif atas sebidang tanah. Hak perseorangan ini akan kembali ke dalam kekuasaan hak ulayat jika ditelantarkan menjadi belukar atau hutan kembali. ${ }^{24}$

Kepemimilikan tanah masyarakat adat, berangkat dari pandangan religius yang menganggap tanah sebagai bagian dari alam semesta ciptaan Ilahi untuk kepentingan makhluknya. Manusia sebagai salah satu bagian dari makhluk berupaya mencari apa yang menjadi kebutuhannya, memanfaatkan apa yang diperoleh dan menggali terus sumber daya alam yang lebih baru dan lebih banyak dibanding kehidupan masa sebelumnya. Karena lahan pertanahan saat itu tak terukur luasnya, tidak jelas subyek dan batasnya, maka tanah hanya dapat dikuasai secara ipso facto. Artinya, tanah dipandang dikuasai apabila secara kasat inderawi telah nyata-nyata ditempati, dimanfaatkan dan diusahakan serta dirawat orang, baik sebagai pemukim maupun

\footnotetext{
${ }^{21}$ Ibid.

${ }^{22}$ Ibid.

${ }^{23}$ R. van Dijk, Pengantar Hukum Adat Indonesia, terjemahan Soehardi, Alumni, Bandung, 1964, hlm. 12

${ }^{24}$ Achmad Sodiki, Loc.Cit.
} 
penggarap. ${ }^{25}$ Dengan demikian, dalam konsep lokal, keamanan pemilikan tanah tidak diukur dengan selembar kertas yang disebut sertifikat, tetapi didasarkan pada riwayat penggarapan tanah secara turun temurun, pengakuan tokoh adat dan kesaksian orang lain. ${ }^{26}$

Dalam konsep Barat yang diperkenalkan oleh Pemerintah Hindia Belanda, kepemilikan tanah didalilkan secara ipso-jure, yaitu berdasarkan pembenaran yuridis. Hak Gubernur Hindia Belanda atas tanah, semula didalilkan secara ipso-jure dari penguasa pribumi melalui kontrak panjang (lange contracten) atau pernyataan pendek (korte verklaringen). Ini merupakan perjanjian-perjanjian politik antara raja-raja pribumi dan Pemerintah Hindia Belanda, seperti : kontrak panjang Kesusunan Solo, Kesultanan Yogyakarta, dan Deli, pernyataan pendek Kesultanan Goa, Bone dan sebagainya. ${ }^{27}$

Bertolak dari konsep penguasaan tanah secara ipso-jure, kemudian dicarikan alat pembenar yuridis yang permanen, berupa Agrarische Wet (S.1870 No.55). Dalam undang-undang ini, dinyatakan bahwa tanah-tanah di Jawa dan Madura yang tidak dapat dibuktikan sebagai tanah hak kepunyaan (eigendom) adalah domein negara. ${ }^{28}$ Dengan berlakunya pernyataan domein ini, maka negara sebagai pemilik tanah dapat menyewakan tanah kepada para pemilik modal berdasarkan KUH Perdata yang memunculkan hak erfact, dan dapat memberantas apa yang disebut pendudukan tanah secara tidak sah. Faktor yuridis ini menjadi faktor penentu peniadaan kemutlakan hak-hak masyarakat adat dan warganya atas tanah-tanah dan lahan warisan nenek moyang mereka secara ipso fakto. Sekalipun demikian, penggabungan kedua konsep tersebut, dapat terlihat ketika hak-hak rakyat masih memperoleh pengakuan de facto sebagai bezitrecht yang dapat dimohonkan pengakuan de jure sebagai eigendom. ${ }^{29}$

Uraian di atas menunjukkan bahwa sebelum Indonesia menjadi negara yang merdeka, bahkan hingga terbentuknya hukum pertanahan nasional dalam UUPA, terdapat dualisme hukum pertanahan di Indonesia. Pada satu sisi, berlaku hukum negara (Pemerintah Hindia Belanda), yang didasarkan pada teori domein dengan kepemilikan secara ipso jure, sesuai dengan ketentuan-ketentuan dalam Buku II KUH

\footnotetext{
${ }^{25}$ Soetandyo Wignyosoebroto, Tanah Negara, Tanah Adat yang Dinasionalisasi, Elsam, Jakarta, 1996.

${ }^{26}$ Ade Saptomo, Op.Cit, hlm. 91.

${ }^{27}$ Muslimin, Aspek-Aspek Hukum Otonomi Daerah, Alumni, Bandung, hlm. 14.

${ }^{28}$ Achmad Sodiki, Loc.Cit.

${ }^{29}$ Ade Saptomo, Op.Cit., hlm. 67
} 
Perdata, sedangkan pada sisi lain, juga berlaku hukum rakyat dengan penguasaan tanah dalam tradisi kerajaan Jawa tradisional, serta hukum rakyat berdasarkan hak ulayat, dengan kepemilikan secara ipso facto.

UUPA sebagai hukum pertanahan nasional, bermaksud menghilangkan dualisme hukum pertanahan, dan secara sadar hendak mengadakan kesatuan hukum. ${ }^{30}$ Dalam melakukan kesatuan hukum tersebut, UUPA tidak dibentuk berdasarkan asas "domein" (menyatakan negara sebagai pemilik atas tanah) sebagaimana yang dipergunakan oleh hukum negara kolonial. ${ }^{31}$ Tidak juga didasarkan pada penguasaan tanah yang berlaku dalam kerajaan jawa tradisional, yang menganut prinsip yang sama dengan asas "domein". ${ }^{32}$ UUPA, dibentuk berdasarkan pada ketentuan-ketentuan hukum adat, agar sesuai dengan kesadaran hukum rakyat banyak, mengingat sebahagian besar rakyat tunduk kepada hukum adat. ${ }^{33}$

Pemikiran dalam UUPA yang menyatakan bahwa hukum pertanahan nasional didasarkan pada hukum adat, diantaranya nampak dalam konsep hubungan bangsa Indonesia dengan tanah (hak bangsa) dan hak menguasai negara atas tanah. UUPA menggambarkan hubungan bangsa Indonesia dengan tanah, sebagai semacam hubungan hak ulayat yang diangkat pada tingkatan yang mengenai seluruh wilayah negara. ${ }^{34}$

Sebagaimana halnya dalam hak ulayat; yang memberikan hak dan kebebasan kepada persekutuan dan setiap anggotanya untuk memperoleh manfaat terhadap tanah ulayat; sepanjang tidak bersentuhan dengan hak anggota persekutuan yang lain dan melarang orang luar persekutuan untuk mengambil manfaat atas tanah tanpa izin dan pembayaran pengakuan (recognetie), dan melarang orang luar persekutuan mempunyai hak milik perseorangan atas tanah persekutuan, ${ }^{35}$ maka hak bangsa juga memberikan hak kepada negara dan setiap warga negara Indonesia untuk memanfaatkan tanah diseluruh wilayah Indonesia, ${ }^{36}$ dan melarang warga negara asing untuk mempunyai hak milik atas tanah. ${ }^{37}$

Demikian juga, dalam lingkup hak ulayat, terdapat hak individual atas tanah, yang lahir karena pengusahaan yang terus menerus secara intensif atas sebidang

\footnotetext{
${ }^{30}$ Penjelasan Umum Angka III angka (1) UU No. 5 Tahun 1960 tentang Peraturan Dasar Pokok-Pokok Agraria

${ }^{31}$ Penjelasan Umum Angka II angka (2) UU No. 5 Tahun 1960 tentang Peraturan Dasar Pokok-Pokok Agraria.

${ }^{32}$ Achmad Sodiki, Op.Cit.

${ }^{33}$ Penjelasan Umum Angka III angka (1) UU No. 5 Tahun 1960, tentang Peraturan Dasar Pokok-Pokok Agraria.

${ }^{34}$ Penjelasan Umum Angka II angka (1) UU No. 5 Tahun 1960 tentang Peraturan Dasar Pokok-Pokok Agraria.

${ }^{35}$ R. van Dijk, Loc.Cit.

${ }^{36}$ Penjelasan Umum Angka II angka (3) UU No.5 Tahun 1960

${ }^{37}$ Penjelasan Umum Angka II angka (5) UU No.5 Tahun 1960
} 
tanah. Hak perseorangan ini akan kembali ke dalam kekuasaan hak ulayat jika ditelantarkan menjadi belukar atau hutan kembali. ${ }^{38}$ Bertolak dari konsep ini, dalam UUPA dimunculkan fungsi sosial tanah, yang melarang seseorang menggunakan atau tidak menggunakan tanah sehingga merugikan kepentingan masyarakat. ${ }^{39}$

Berdasarkan hak bangsa Indonesia, kepada negara sebagai organisasi kekuasaan dari bangsa Indonesia, diberikan hak menguasai negara atas tanah, yang meliputi semua tanah; baik yang sudah dihaki oleh seseorang maupun yang tidak. ${ }^{40}$ Ini berbeda dengan konsepsi hak ulayat, karena obyek hak ulayat, hanya meliputi bidang-bidang tanah yang belum dihaki oleh seseorang ${ }^{41}$ Demikian juga, wewenang negara untuk mencabut hak seseorang atas tanah demi kepentingan umum, termasuk kepentingan bangsa dan negara serta kepentingan bersama dari rakyat ${ }^{42}$ tidak lagi menggambarkan fungsi sosial tanah dalam konsepsi asli hak ulayat, karena fungsi sosial tanah dalam hak ulayat hanya berkaitan dengan tanah tidak digunakan (penelantaran tanah). ${ }^{43}$ atau karena penggunaan tanah yang merugikan kepentingan anggota persekutuan.

UUPA juga membatasi hak ulayat masyarakat hukum adat; agar sesuai dengan kepentingan nasional dan negara serta tidak boleh bertentangan dengan undangundang dan peraturan lain yang lebih tinggi. ${ }^{44}$ UUPA menegaskan bahwa hukum agraria yang berlaku ialah hukum adat, sepanjang tidak bertentangan dengan kepentingan nasional dan negara, tidak bertentangan dengan sosialisme Indonesia serta tidak pula bertentangan dengan peraturan-peraturan dalam UUPA dan dengan peraturan perundangan lainnya. ${ }^{45}$

Ketentuan UUPA yang demikian, menunjukkan bahwa hukum adat yang menjadi hukum agraria nasional itu, bukanlah hukum adat sebagaimana yang hidup dalam masyarakat (living law), melainkan hukum adat yang telah diubah berdasarkan kreasi negara, dengan alasan untuk disesuaikan dengan kepentingan masyarakat dalam negara yang modern dan dalam hubungannya dengan dunia internasional. ${ }^{46}$

\footnotetext{
${ }^{38}$ Achmad Sodiki, Loc.Cit.

${ }^{39}$ Penjelasan Umum Angka II angka (4) UU No.5 Tahun 1960

${ }^{40}$ Penjelasan Umum Angka II angka (2) UU No.5 Tahun 1960 tentang Peraturan Dasar Pokok-Pokok Agraria, Lihat Juga Boedi Harsono, Menuju Penyempurnaan Hukum Tanah Nasional Dalam Hubungannya Dengan Tap MPR-RI No.IX/MPR/2001, Uiverstitas Trisakti, Jakarta.2002, hlm. 40-41

${ }^{41}$ Muhammad Bakri, Hak Menguasai Tanah Oleh Negara, Paradigma Baru Untuk Reformasi Agraria, Citra Media, Yogyakarta, 2007, hlm. 111.

${ }^{42}$ Pasal 18 UU No.5 Tahun 1960

${ }^{43}$ Achmad Sodiki, Loc.Cit

${ }^{44}$ Pasal 3 UU No. 5 Tahun 1960

${ }^{45}$ Pasal 5 UU No. 5 Tahun 1960

${ }^{46}$ Penjelasan Umum Angka III angka (1) UU No.5 Tahun 1960 tentang Peraturan Dasar Pokok-Pokok Agraria
} 
Kreasi negara juga terlihat dari tujuan UUPA yang ingin memberikan kepastian hukum mengenai hak-hak atas tanah, dengan mewajibkan para pemegang hak untuk mendaftarkan tanahnya serta adanya instruksi kepada pemerintah untuk menyelenggarakan pendaftaran tanah. ${ }^{47}$ Dengan ketentuan ini berarti UUPA meninggalkan tradisi kepemilikan tanah secara ipso facto dalam masyarakat hukum adat menjadi kepemilikan tanah secara ipso-jure, yang dikenal dalam hukum Barat. ${ }^{48}$

Berdasarkan uraian di atas, hukum pertanahan nasional dalam UUPA tersebut, sudah tidak lagi sebangun dengan hukum adat, sebagai hukum yang hidup di kalangan rakyat. Hukum adat diakui sebagai hukum tetapi posisinya diletakkan di bawah subordinasi hukum negara.

Keadaan yang demikian menunjukkan adanya situasi bahwa di dalam masyarakat Indonesia, selain berlaku hukum negara (state law) berupa peraturan perundangundangan, juga berlaku hukum adat (customary law). John Griffith, menyebut situasi yang demikian sebagai pluralisme hukum lemah (weak legal pluralism). Pluralisme hukum lemah merupakan bentuk lain dari sentralisme hukum (legal centralism), sebab walaupun hukum negara (legal state) mengakui hukum adat, tetapi hukum negara tetap dipandang sebagai superior atau super-ordinasi dalam sistem hukum negara. ${ }^{49}$

Hukum pertanahan yang bercorak sentralistik (legal centralism), mengakibatkan konflik norma (conflict of norm) dengan hukum adat. ${ }^{50}$ Komunitas masyarakat adat masih menggunakan prinsip dan kaidah hukum adat dalam penguasaan dan penggunaan tanah, sementara UUPA cenderung mengabaikan dan mendesak norma-norma hukum adat yang ada dalam masyarakat, yang kemudian berujung pada sengketa dalam pengadaan tanah untuk kepentingan umum.

\section{Prosedur Pengadaan Tanah Untuk Kepentingan Umum}

Pengadaan tanah untuk kepentingan umum, dapat ditempuh melalui dua cara, yaitu melalui pencabutan hak (secara paksa) ${ }^{51}$ dan melalui musyawarah (dengan

\footnotetext{
${ }^{47}$ Penjelasan Umum Angka I dan angka IV serta Pasal 23, 32, 38 serta Pasal 19 UU No. 5 Tahun 1960

${ }^{48}$ Soetandyo Wignyosoebroto, Loc.Cit.

${ }^{49}$ John Griffith sebagaimana yang dikomentarkan oleh Tamanaha, dalam Nyoman Nurjaya, Reorientasi Paradigma Pembangunan Hukum Negara Dalam Masyarakat Multikultural, Perspektif Hukum Progresif, Makalah Seminar Hukum Progresif, Fakultas Hukum Undip bekerja sama dengan Program Doktor Ilmu Hukum Undip dan Fakultas Hukum Universitas Trisakti, Semarang, 15 Desember 2007

${ }^{50}$ Nyoman Nurjaya, Ibid.

${ }^{51}$ Sebagaimana yang diatur dalam UU No. 20 Tahun 1961 tentang Pencabutan Hak-Hak Atas Tanah dan BendaBenda Yang Ada Di Atasnya serta Inpres No. 9 Tahun 1973 tentang Pedoman Pelaksanaan Pencabutan Hak Atas Tanah dan Benda-Benda Yang Ada Di Atasnya.
} 
persetujuan pemegang hak). ${ }^{52}$ Pengadaan tanah untuk kepentingan umum melalui pencabutan hak, merupakan kewenangan Presiden yang tidak dilimpahkan kepada pajabat lain. ${ }^{53}$

Pencabutan hak pada dasarnya dihindari, dan hanya dilakukan dalam keadaan yang memaksa, yaitu apabila jalan melalui musyawarah untuk memperoleh tanah demi kepentingan umum dengan persetujuan pemiliknya, tidak membawa hasil yang diharapkan. ${ }^{54}$ Keputusan Pencabutan hak dilakukan dengan Keputusan Presiden, setelah mendengar pertimbangan Menteri Agraria, Menteri Kehakiman dan Menteri Terkait yang memerlukan tanah. Dengan demikian, pencabutan hak adalah jalan terakhir untuk memperoleh tanah dan atau benda-benda lainnya yang diperlukan untuk kepentingan umum. Pencabutan Hak harus dilakukan menurut cara yang diatur dengan Undang-Undang dan kepentingan dari yang empunya tetap harus diperhatikan dengan memberikan ganti kerugian yang layak..$^{55}$

Ganti kerugian dalam pencabutan hak, ditetapkan oleh Presiden, atas usul suatu Panitia Penaksir yang susunan dan tata kerjanya ditetapkan oleh Menteri Agraria. ${ }^{56}$ Ganti kerugian yang layak itu didasarkan atas nilai nyata/sebenarnya dari tanah atau benda-benda yang bersangkutan. Harga yang didasarkan pada nilai nyata/sebenarnya itu tidak mesti sama dengan harga umum, karena harga umum bisa merupakan harga "catut". Tetapi sebaliknya, harga tersebut tidak pula berarti harga yang murah. ${ }^{57}$ Besarnya ganti kerugian tersebut, tidak boleh menyebabkan keadaan sosial dan ekonomi bekas pemegang hak menjadi mundur. ${ }^{58}$ Orang-orang yang berhak mendapatkan ganti kerugian bukan hanya orang-orang yang berhak atas tanah tetapi juga orang-orang yang menempati rumah atau menggarap tanah yang bersangkutan. ${ }^{59}$

Dalam praktik, pengadaan tanah untuk kepentingan umum melalui pencabutan hak yang hanya merupakan kewenangan Presiden tersebut jarang dilakukan. Hal

${ }^{52}$ Sebagaimana diatur dalam Permendagri No.15 Tahun 1975 tentang Ketentuan-Ketentuan Mengenai Tata Cara Pembebasan Tanah, yang telah diubah dengan Kepres No.55 Tahun 1993 tentang Pengadaan Tanah Bagi Pelaksanaan Pembangunan Untuk Kepentingan Umum, yang kemudian diubah dengan Perpres No.36 Tahun 2005, serta telah diubah kembali dengan Perpres No. 65 Tahun 2006.

${ }^{53}$ Penjelasan Umum angka (4) huruf a UU No.20 Tahun 1961 tentang Pencabutan Hak-Hak Atas Tanah Dan Benda-Benda Yang Ada di Atasnya.

${ }^{54}$ Penjelasan Umum Angka (2) UU No.20 Tahun 1961

${ }^{55}$ Pasal 18 UU No.5 Tahun 1960 tentang Peraturan Dasar Pokok-Pokok Agraria.

${ }^{56}$ Pasal 4 UU No.20 Tahun 1961

${ }^{57}$ Penjelasan Umum Angka (5). UU No. 20 Tahun 1961

${ }^{58}$ Penjelasan Umum PP No.39/1973 tentang Acara Penetapan Ganti Kerugian Oleh Pengadilan Tinggi Sehubungan dengan Pencabutan Hak-Hak Atas Tanah Dan Benda-Benda Yang Ada Di Atasnya.

${ }^{59}$ Penjelasan Umum angka (5) UU No.20 Tahun 1961 tentang Pencabutan Hak-Hak Atas Tanah dan BendaBenda Yang Ada Di Atasnya. 
itu disebabkan karena pengadaan tanah untuk kepentingan umum melalui pencabutan hak, hanya dilakukan apabila jalan untuk memperoleh persetujuan pemiliknya melalui musyawarah tidak membawa hasil yang diharapkan. ${ }^{60}$

Musyawarah adalah proses atau kegiatan saling mendengar dengan sikap saling menerima pendapat dan keinginan yang didasarkan atas kesukarelaan antara pemilik hak atas tanah dan pihak yang memerlukan tanah, untuk memperoleh kesepakatan mengenai bentuk dan besarnya ganti kerugian. ${ }^{61}$

Apabila memperhatikan peraturan perundang-undangan yang mengatur tentang tata cara pengadaan tanah untuk kepentingan umum yang berlaku serta pernah berlaku dan dilaksanakan dalam praktik pengadaan tanah untuk kepentingan umum, musyawarah yang dimaksudkan itu hanya bersifat formalitas, sebab besarnya ganti kerugian sesungguhnya telah ditentukan oleh Pemerintah. Dalam apa yang disebut musyawarah itu, bentuk dan besarnya ganti kerugian ditetapkan oleh Panitia Pengadaan Tanah berdasarkan ketentuan yang telah ditetapkan oleh Pemerintah, sedangkan pendapat dan keinginan pemilik tanah menentukan. ${ }^{62}$

Dalam pengadaan tanah melalui musyawarah, sebagaimana yang diatur dengan Permendagri No. 15 Tahun 1975 tentang Ketentuan-Ketentuan Mengenai Tata Cara Pembebasan Tanah, penetapan ganti kerugian ditaksir dan ditentukan oleh Panitia Pembebasan Tanah, setelah mengadakan musyawarah dengan para pemilik hak atas tanah berdasarkan harga umum setempat. ${ }^{63}$ yaitu harga dasar yang ditetapkan secara berkala oleh suatu Panitia untuk sesuatu daerah menurut jenis penggunaannya. ${ }^{64}$ Sedangkan ganti rugi atas bangunan dan tanaman berpedoman pada ketentuan yang telah ditetapkan oleh Dinas Pekerjaan Umum/Dinas Pertanian setempat, bentuk ganti rugi dapat berupa uang, tanah dan atau fasilitas-fasilitas lain, sedangkan yang berhak atas ganti rugi itu ialah mereka yang berhak atas tanah/bangunan/tanaman yang ada di atasnya, dengan berpedoman kepada hukum adat setempat, sepanjang tidak bertentangan dengan ketentuan-ketentuan UUPA dan Kebijaksanaan Pemerintah. ${ }^{65}$

\footnotetext{
${ }^{60}$ Penjelasan Umum angka (2) UU No. 20 Tahun 1961 tentang Pencabutan Hak-Hak Atas Tanah dan BendaBenda Yang Ada Di Atasnya.

${ }^{61}$ Pasal 1 angka 5 Kepres No. 55 Tahun 1993 tentang Pengadaan Tanah Bagi Pelaksanaan Pembangunan Untuk Kepentingan Umum.

${ }^{62}$ Bentuk dan besarnya ganti kerugian pada semua kasus sengketa yang ditemukan dalam studi ini ditetapkan secara sepihak oleh Panitia Pengadaan Tanah, tanpa memperhatikan pendapat dan keinginan pemilik tanah.

${ }^{63}$ Pasal 6 ayat (1) Permendagri No. 15 Tahun 1975 tentang Ketentuan-Ketentuan Mengenai Tata Cara Pembebasan Tanah.

${ }^{64}$ Pasal 1 ayat (4) Permendagri No. 15 Tahun 1975
${ }^{65}$ Pasal 6 ayat (2) Permendagri No. 15 Tahun 1975
} 
Dalam Kepres No. 55 Tahun 1993 tentang Pengadaan Tanah Bagi Pelaksanaan Pembangunan Untuk Kepentingan Umum. ${ }^{66}$ Musyawarah penentuan ganti kerugian tersebut harus dilakukan secara langsung antara pemegang hak atas tanah yang bersangkutan dan instansi Pemerintah yang memerlukan tanah. Musyawarah tersebut dipimpin oleh Panitia Pengadaan Tanah, dan hanya dalam hal jumlah pemegang hak atas tanah tidak memungkinkan terselenggaranya musyawarah secara efektif, musyawarah dapat dilakukan dengan wakil-wakil yang ditunjuk diantara dan oleh para pemegang hak atas tanah, yang sekaligus selaku kuasa mereka. ${ }^{67}$

Ganti kerugian dalam rangka pengadaan tanah diberikan untuk hak atas tanah, bangunan, tanaman dan benda-benda lain yang berkaitan dengan tanah. ${ }^{68}$ Bentuk ganti kerugian dapat berupa uang, tanah pengganti, pemukiman kembali, gabungan dari dua atau lebih dari bentuk ganti kerugian tersebut, atau bentuk lain yang disetujui oleh pihak-pihak yang bersangkutan. ${ }^{69}$ Khusus terhadap bidang tanah yang dikuasai dengan hak ulayat, diberikan dalam bentuk pembangunan fasilitas umum atau bentuk lain yang bermanfaat bagi masyarakat setempat. ${ }^{70}$

Bentuk dan besarnya ganti kerugian atas tanah didasarkan atas nilai nyata atau sebenarnya, dengan memperhatikan NJOP Bumi dan Bangunan yang terakhir untuk tanah yang bersangkutan, nilai jual bangunan yang ditaksir oleh instansi Pemerintah Daerah yang bertanggungjawab di bidang bangunan, dan nilai jual tanaman yang ditaksir oleh instansi Pemerintah Daerah yang bertanggungjawab di bidang pertanian. ${ }^{71}$ Bentuk dan besarnya ganti kerugian atas dasar cara perhitungan dimaksud, ditetapkan dalam musyawarah. ${ }^{72}$ Apabila terjadi kesepakatan antara pemegang hak atas tanah dan instansi Pemerintah yang memerlukan tanah, maka Panitia Pengadaan Tanah mengeluarkan keputusan mengenai bentuk dan besarnya ganti kerugian sesuai dengan kesepakatan tersebut. ${ }^{73}$ Dalam hal musyawarah sudah dilakukan berulangkali dan kesepakatan mengenai bentuk dan besarnya ganti

\footnotetext{
${ }^{66}$ Pasal 9 Kepres No. 55 Tahun 1993 tentang Pengadaan Tanah Bagi Pelaksanaan Pembangunan Untuk Kepentingan Umum.

${ }^{67}$ Pasal 10 ayat (1), (2) dan (3) Kepres No. 55 Tahun 1993

${ }^{68}$ Pasal 12 Kepres No. 55 Tahun 1993

${ }^{69}$ Pasal 13 Kepres No. 55 Tahun 1993

${ }^{70}$ Pasal 14 Kepres No. 55 Tahun 1993

${ }^{71}$ Pasal 15 Kepres No. 55 Tahun 1993 tentang Pengadaan Tanah Bagi Pelaksanaan Pembangunan Untuk Kepentingan Umum.

${ }^{72}$ Pasal 16 Kepres No. 55 Tahun 1993

${ }^{73}$ Pasal 18 Kepres No. 55 Tahun 1993
} 
kerugian tidak tercapai juga, maka bentuk dan besarnya ganti kerugian ditetapkan oleh Panitia Pengadaan tanah, dengan sejauh mungkin memperhatikan pendapat, keinginan, saran dan pertimbangan yang berlangsung dalam musyawarah. ${ }^{74}$

Dalam Perpres No. 36 Tahun 2005 tentang Pengadaan Tanah Bagi Pelaksanaan Pembangunan Untuk Kepentingan Umum, juga disebutkan bahwa pengadaan tanah bagi pelaksanaan pembangunan untuk kepentingan umum dilakukan melalui musyawarah, dalam rangka memperoleh kesepakatan mengenai dua hal, yaitu mengenai pelaksanaan pembangunan untuk kepentingan umum di lokasi tersebut, dan mengenai bentuk dan besarnya ganti rugi. ${ }^{75}$

Musyawarah tersebut harus dilaksanakan secara langsung antara pemegang hak atas tanah, bangunan, tanaman dan benda-benda lain yang berkaitan dengan tanah bersama dengan Panitia Pengadaan Tanah dan Instansi Pemerintah atau Pemerintah Daerah yang memerlukan tanah. Hanya dalam hal jumlah pemegang hak atas tanah tidak memungkinkan terselenggaranya musyawarah secara efektif, maka musyawarah dapat dilakukan oleh panitia pengadaan tanah dan instansi pemerintah atau pemerintah daerah yang memerlukan tanah dengan wakil-wakil yang ditunjuk diantara dan oleh para pemegang hak atas tanah, yang sekaligus bertindak sebagai kuasa mereka. Penunjukkan wakil atau kuasa tersebut, dilakukan secara tertulis, bermaterai cukup yang diketahui oleh Kepala Desa/Lurah atau surat penunjukkan kuasa yang dibuat dihadapan pejabat yang berwenang. Musyawarah tersebut dipimpin oleh Ketua Panitia Pengadaan Tanah. ${ }^{76}$

Jika dalam musyawarah tersebut dicapai kesepakatan antara pemegang hak atas tanah dan instansi Pemerintah dan atau pemerintah Daerah yang memerlukan tanah, Panitia Pengadaan Tanah mengeluarkan keputusan mengenai bentuk dan besarnya ganti rugi sesuai dengan kesepakatan tersebut. ${ }^{77}$ Akan tetapi, dalam hal tidak tercapai kesepakatan, maka Panitia Pengadaan Tanah menetapkan sendiri bentuk dan besarnya ganti rugi tersebut ${ }^{78}$ Perhitungan besarnya ganti rugi didasarkan pada NJOP atau nilai nyata/sebenarnya dengan memperhatikan NJOP tahun berjalan berdasarkan penetapan Lembaga/Tim Panitia Harga Tanah yang

\footnotetext{
${ }^{74}$ Pasal 19 Kepres No. 55 Tahun 1993

${ }^{75}$ Pasal 8 Perpres No. 36 Tahun 2005 tentang Pengadaan Tanah Bagi Pelaksanaan Pembangunan Untuk Kepentingan Umum.

${ }^{76}$ Pasal 9 Perpres No. 36 Tahun 2005 tentang Pengadaan Tanah Bagi Pelaksanaan Pemangunan Untuk Kepentingan Umum.

${ }^{77}$ Pasal 11 Perpres No. 36 Tahun 2005

${ }^{78}$ Pasal 10 ayat (2) Perpres No. 36 Tahun 2005
} 
ditunjuk oleh Panitia. Nilai jual bangunan ditaksir oleh perangkat daerah yang bertanggungjawab di bidang bangunan dan nilai jual tanaman ditaksir oleh perangkat daerah yang bertanggungjawab di bidang pertanian. Lembaga/Tim Penilai harga tanah ditetapkan oleh Bupati/Walikota atau Gubernur bagi Provinsi DKI Jakarta. ${ }^{79}$

Berdasarkan peraturan perundang-undangan di atas, nyatalah bahwa dalam musyawarah penentuan ganti kerugian, besarnya ganti kerugian yang akan dimusyawarahkan itu, pada dasarnya sudah ditentukan oleh Pemerintah. Besarnya ganti kerugian atas tanah didasarkan atas harga umum setempat yang ditetapkan secara berkala (NJOP), ganti kerugian atas bangunan didasarkan atas taksiran instansi pemerintah yang bertanggungjawab dibidang bangunan, dan ganti kerugian atas tanaman didasarkan atas taksiran instansi pemerintah yang bertanggungjawab di bidang pertanian.

Adanya ketentuan yang demikian, menyebabkan musyawarah yang dilakukan dalam penentuan besarnya ganti kerugian, bukan untuk mendengar dan menerima pendapat serta keinginan para pemilik hak atas tanah, melainkan agar para pemilik hak atas tanah mendengar dan menerima ketentuan ganti kerugian yang ditetapkan oleh Pemerintah. Hal yang demikian pada hakikatnya sama saja dengan penentuan ganti kerugian secara sepihak oleh pemerintah dan bukan atas dasar musyawarah dengan para pemilik hak atas tanah. Besarnya ganti kerugian yang ditetapkan secara sepihak oleh Panitia Pengadaan Tanah tersebut, ternyata dinilai tidak layak dan ditolak oleh para pemilik tanah, karena tidak mencukupi kebutuhan mereka untuk melanjutkan kehidupan seperti sebelumnya. ${ }^{80}$ sehingga menimbulkan terjadinya sengketa.

Meminjam pemikiran Dahrendorf, maka dapat dikatakan bahwa konflik terjadi karena adanya pola hubungan superordinasi dan subordinasi antara kepentingan negara dan kepentingan perseorangan ${ }^{81}$ Lembaga (struktrur) hukum pengadaan

\footnotetext{
${ }^{79}$ Pasal 15 Perpres No. 36 Tahun 2005

${ }^{80}$ Dalam Kasus sengketa pengadaan tanah untuk pembangunan Asrama TNI di Dusun Besar Kecamatan Talang IV Bengkulu Utara, pemilik tanah menolak ganti kerugian karena dua alasan, pertama hak mereka atas tanah tidak diakui sehingga tidak diberi ganti kerugian, kedua, ganti kerugian yang diberikan atas tanaman, mereka nilai sangat tidak layak, karena tidak mencukupi untuk menanam kembali sampai kembali memberikan hasil seperti tanaman mereka yang diambil pemerintah. H. Ibrahim, dkk, wawancara pribadi, Desember 2009. Hal serupa juga dialami oleh Siham dkk, dalam kasus sengketa pengadaan lahan perkebunan sawit bagi PT. Bio Nusantara Teknologi di Kecamatan Pondok Kelapa Bengkulu Utara. Siham, wawancara pribadi, Febuari 2010.

${ }^{81}$ Dahrendorf, dalam George Ritzer-Douglas J. Goodman, Teori Sosiologi Modern, edisi keenam, alih bahasa oleh Alimandan, Penerbit Kencana, Jakarta, 2007, hlm. 155
} 
tanah; Panitia Pengadaan Tanah, (yang seluruhnya terdiri dari unsur aparat pemerintahan tersebut), bukanlah lembaga yang netral, melainkan sengaja dibentuk untuk kepentingan pemerintah dengan tugas agar dapat menyediakan tanah bagi kepentingan umum, dengan prosedur kerja yang kaku, agar dapat bekerja secara mekanis. Dahrendorf mengemukakan bahwa seseorang akan berperilaku sesuai dengan posisinya, yaitu berupa harapan (peran) yang dilekatkan pada posisi mereka untuk dapat menyediakan tanah bagi kepentingan pemerintah, ${ }^{82}$ dengan cara menerapkan peraturan tentang standar harga ganti kerugian yang telah ditetapkan sepihak oleh Pemerintah.

\section{Budaya Hukum Aparat Pelaksana Pengadaan Tanah untuk Kepentingan Umum Terbelenggu oleh Cara Berpkir Legal Positivisme}

Praktik pengadaan tanah untuk kepentingan umum, juga ditandai oleh sikap dan tindakan aparat Pelaksana Pengadaan Tanah, terlihat sangat mendasarkan diri pada tradisi legal positivisme, yang memandang hukum sebagai peraturan perundang-undangan dan perintah (instruksi) dari Pejabat yang berwenang, ${ }^{83}$ dan megabaikan hukum adat sebagai hukum yang hidup dalam masyarakat (living law). Sementara dalam kehidupannya berkaitan dengan penguasaan dan penggunaan tanah, kebanyakan masyarakat, masih mengikuti tradisi dan hukum adatnya serta tidak memahami sistem hukum pertanahan dalam peraturan perundangundangan. $^{84}$

Sikap aparat Panitia Pengadaan Tanah, yang menghendaki agar pemilik tanah menunjukkan alat bukti tertulis atas klaimnya terhadap pemilikan tanah yang dimilikinya, untuk dapat diakui dan diberikan ganti kerugian, ${ }^{85}$ merupakan pengabaian terhadap hukum adat, karena dalam hukum adat, hubungan antara warga masyarakat dengan lahan tidak diukur dengan selembar kertas yang disebut sertifikat, tetapi oleh riwayat penggarapan tanah secara turun temurun, pengakuan tokoh adat dan kesaksian orang lainlah yang menjadi penentu. ${ }^{86}$

\footnotetext{
${ }^{82}$ Ibid., hlm. 156.

${ }^{83}$ Panitia Pengadaan Tanah Untuk Kepentingan Umum, dalam semua Kasus Sengketa yang diteliti selalu mendalilkan bahwa tindakannya sudah sesuai dengan prosedur dan peraturan perundang-undangan yang berlaku.

${ }^{84}$ Disimpulkan dari sikap dan pandangan para pemilik hak atas tanah dalam kasus sengketa Pengadaan Tanah Untuk Kpentingan Umum, baik melalui wawancara maupun berdasarkan dokumen putusan pengadilan. terkena

${ }^{85}$ Sebagaimana yang dituturkan oleh $\mathrm{H}$. Ibrahim, dkk, dalam kasus pengadaan tanah untuk pembangunan Asrama TNI di Dusun Besar Kecamatan Talang IV Kabupaten Bengkulu Utara, Wawancara Pribadi, Desember 2009.

${ }^{86}$ Ade Saptomo, Op.Cit., hlm. 68
} 
Kepemilikan tanah dalam masyarakat hukum adat terjadi secara ipso facto, artinya tanah dipandang sudah dikuasai apabila secara kasat inderawi telah nyatanyata ditempati, dimanfaatkan dan diusahakan serta dirawat oleh orang baik sebagai pemukim atau penggarap. ${ }^{87}$ Ini berarti bahwa kepastian hukum pemilikan tanah dalam hukum adat, tidak dapat dipahami menurut perspektif ipso jure sebagaimana yang dikehendaki oleh UUPA, ${ }^{88}$ melainkan harus dipahami menurut perspektif hukum adat itu sendiri.

Memahami kepastian hukum pemilikan tanah dalam hukum adat dengan menggunakan perspektif peraturan perundang-undangan, mengakibatkan kepemilikan tanah berdasarkan hukum adat menjadi tidak diakui. Pada kasus sengketa pengadaan tanah untuk pembangunan Asrama TNI di Dusun Besar Marga Proatin XII Kecamatan Talang IV Kabupaten Bengkulu Utara Panitia Pengadaan Tanah, sama sekali tidak memberikan ganti kerugian atas tanah kepada pemiliknya, melainkan hanya memberikan ganti kerugian atas tanaman, karena menurut Panitia Pengadaan tanah, pemiliknya tidak dapat memperlihatkan adanya cukup bukti hak atas tanah sebagaimana yang diatur dalam peraturan perundang-undangan. ${ }^{89}$ Dalam kasus ini, Panitia Pengadaan Tanah jelas-jelas telah menggunakan cara pandang legal-positivis, sehingga tidak dapat melihat adanya kepemilikan hak atas tanah berdasarkan hukum adat secara ipso facto. Para pemilik tanah menolak tindakan pemerintah yang mengambil tanah mereka dengan tanpa memberikan ganti kerugian tersebut, karena dianggap sebagai tindakan yang tidak berkeadilan.

Sikap yang sama, juga terlihat dalam kasus sengketa pengadaan tanah untuk kepentingan perkebunan sawit bagi PT. Bio Nusantara Teknologi di Kecamatan Pondok Kelapa Kabupaten Bengkulu Utara. Para pemilik tanah tidak diberi ganti kerugian atas tanah yang mereka miliki. ${ }^{90}$ Kepada mereka tidak diberikan ganti kerugian atas tanah, melainkan hanya diberikan ganti kerugian atas tanam tumbuh. ${ }^{91}$

\footnotetext{
${ }^{87}$ Soetandyo Wignyosoebroto, Tanah Negara, Tanah Adat yang Dinasionalisasi, Elsam, Jakarta, 1996, hlm. 22

${ }^{88}$ Sebagaimana yang dikehendaki dalam Pasal 23, 32 dan 38 UU No. 5 Tahun 1960 tentang Peraturan Dasar Pokok-Pokok Agraria.

${ }^{89}$ Seperti yang dituturkan oleh H. Ibrahim, dkk, Pemilik Tanah yang terkena lokasi Pengadaan Tanah untuk pembangunan Asrama TNI di Dusun Besar Kecamatan Talang IV Bengkulu Utara, Wawancara Pribadi, Desember 2009.

${ }^{90}$ Sebagaimana yang dituturkan oleh Siham, pemilik tanah yang terkena lokasi pengadaan tanah untuk kepentingan lahan Perkebunan Sawit Bagi PT. Bio Nusantara Teknologi di Kecamatan Pondok Kelapa Bengkulu Utara, Wawancara Pribadi, Febuari 2010.

${ }^{91}$ Keputusan Gybernur Kepala Daerah Tingkat I Bengkulu No. 187 Tahun 1988 Tentang Pedoman Ganti Rugi Tanam Tumbuh Rakyat Dalam Rangka Pemberian HGU Kepada Perusahaan/Investor Untuk Usaha Perkebunan Besar Dan Agro Bisnis Lainnya di Provinsi Daerah Tingkat I Bengkulu.
} 
Sikap aparat pelaksana pengadaan tanah, yang menghendaki agar kepemilikan tanah yang melulu harus dibuktikan dengan surat (ipso-jure), sesuai dengan peraturan perundang-undangan, merefleksikan bahwa praktik hukum dalam pengadaan tanah untuk kepentingan umum, dibelenggu oleh tradisi berpikir dalam positivisme hukum yang memandang hukum dalam wujudnya sebagai peraturan perundang-undangan. ${ }^{92}$

Positivisme hukum, mengidentikkan hukum sama dengan peraturan perundang-undangan. ${ }^{93}$ Dalam pandangan positivisme, keadilan tidak diberikan berdasarkan nilai-nilai yang hidup dalam masyarakat, melainkan dianggap telah diberikan dengan membentuk hukum positif, ${ }^{94}$ yang kemudian melahirkan konsep keadilan formal. Dengan konsep keadilan formal, segala hal yang disebut adil atau tidak adil, harus ditentukan secara pasti dalam norma-norma yang dipositifkan dalam bentuk peraturan perundang-undangan, ${ }^{95}$ sehingga keadilan dianggap telah diwujudkan dengan menerapkan peraturan perundang-undangan tersebut secara sama kepada semua orang.

Sikap aparat pengadaan tanah, juga ditandai oleh keterikatannya pada tradisi positivisme hukum klasik John Austin, yang memandang hukum sebagai perintah penguasa. Pengadaan tanah untuk kepentingan umum, pada asasnya di dasarkan para persetujuan pemilik tanah, yaitu dengan penyerahan atau pelepasan hak yang dilakukan secara sukarela dari pemiliknya seperti jual-beli, tukar menukar atau lainnya, sehingga pelaksanaannya harus ditempuh melalui cara musyawarah. ${ }^{96}$ Pengambilan tanah secara paksa, hanya dapat dilakukan melalui pencabutan hak, yang merupakan kewenangan Presiden yang tidak didelegasikan kepada pejabat lain. ${ }^{97}$

Dalam praktik pengadaan tanah melalui jalan musyawarah, penguasaan paksa atas tanah, justeru dilakukan atas dasar instruksi dalam Surat Izin Penetapan Lokasi;

${ }^{92}$ Soetandyo Wignyosoebroto, Positivisme dan Doktrin Positivisme Dalam Ilmu Hukum dan Kritik Terbadap Doketrin ini, Materi Pelatihan Penulisan Proposal Thesis dan Disertasi bidang Hukum, Yayasan Dewi Sartika, Semarang, 2005 , hlm. 2

${ }^{93}$ Lili Rasjidi, Dasar-Dasar Filsafat Hukum, PT. Citra Aditya Bakti, Bandung, 1993, hlm. 59

${ }^{94}$ Adji Samekto, Studi Hukum Kritis : Kritik Terhadap Hukum Modern, Badan Penerbit Universitas Diponegoro, Semarang, 2003, hlm. 7

${ }^{95}$ Soetandyo Wignyosoebroto, Dua Paradigma Klasik Dalam Percaturan Filsafat Hukum dan Filsafat Sosial untuk Menjelaskan dan Memahami Hakikat Ketertiban Dalam Kehidupan Bermasyarakat Manusia, Bahan Tutorial Dalam Penulisan Thesis dan Disertasi Bidang Ilmu Hukum, Yayasan Dewi Sartika, Semarang, 2005.

${ }^{96}$ Penjelasan Umum angka (2) UU No.20 Tahun 1961 tentang Pencabutan Hak-Hak Atas Tanah Dan BendaBenda Yang Ada Di Atasnya.

${ }^{97}$ Pasal 1 dan Penjelasan Umum angka (4) huruf a UU No. 20 Tahun 1961 dan Penjelasan Umum angka (4) huruf a 
bahkan sebelum musyawarah penentuan ganti kerugian dilakukan dengan para pemilik tanah, bangunan atau tanaman. ${ }^{98}$ Para pemilik tanah, bangunan atau tanaman, hanya mendapat pemberitahuan bahwa tanahnya terkena lokasi pengadaan tanah untuk kepentingan umum dan mereka diminta untuk segera meninggalkan tanahnya, kemudian diikuti dengan tindakan penggusuran terhadap tanah, bangunan atau tanaman. ${ }^{99}$ Penentuan ganti kerugian terhadap para pemilik tanah, baru dilakukan kemudian setelah tanah dikuasasi (digusur) oleh Pemerintah. ${ }^{100}$

Praktik pengadaan tanah yang demikian ini, kemudian menimbulkan persoalan, ketika terjadi penolakan para pemilik tanah, bangunan atau tanaman terhadap bentuk dan besarnya ganti kerugian yang ditetapkan oleh Panitia Pengadaan Tanah. Pada satu sisi, Peraturan perundang-undangan hanya memberikan tugas kepada Panitia Pengadaan Tanah untuk melakukan pengadakan tanah berdasarkan persetujuan dari pemiliknya. ${ }^{101}$ Demikian juga Gubernur, Bupati/walikota maupun menteri dalam negeri, sama sekali tidak diberi wewenang memaksa para pemilik tanah untuk menerima ganti kerugian yang ditetapkannya dalam penyelesaian tersebut, sementara pada sisi lain, tanah sudah berada dalam penguasaan pemerintah. Pengadaan tanah yang dilakukan secara paksa hanya merupakan kewenangan Presiden, yang tidak didelegasikan kepada pejabat lain. ${ }^{102}$

Apabila para pemilik tanah menolak bentuk dan besarnya ganti kerugian yang telah ditetapkan, maka gubernur, bupati/walikota atau Menteri Dalam Negeri, hanya memiliki dua pilihan, yaitu mengembalikan tanah yang sudah dikuasai dalam keadaan semula kepada para pemiliknya atau mengajukan usul pencabutan hak

${ }^{98}$ Di dalam Surat Izin atau Penetapan Lokasi setiap pengadaan tanah untuk kepentingan umum, selalu ada perintah kepada Direktorat Agraria dan Bupati/Walikota untuk melaksanakan inventarisasi, pengukuran keliling batas masing-masing lokasi serta untuk melaksanakan pengosongan dan pengamanan terhadap tanah yang menjadi lokasi pengadaan tanah untuk kepentingan umum, Drs. HWN. Djangdjaya, mantan Sekretaris Daerah Tingkat I Bengkulu, wawancara pribadi, Januari 2010, Ini berkesesuaian dengan Pasal 3 Surat Keputusan Gubernur Kepala Daerah Tinfkat I Bengkulu No. 398 Tahun 1988 tentang Penetapan Lokasi Penggunaan Tanah Dalam Kotamadya Daeah Tingkat II Bengkulu di Kecamatan Selebar.

${ }^{99}$ Sebagaimana yang dituturkan oleh Para pemilik tanah, bahwa mereka dipaksa meninggalkan tanahnya karena tanah miliknya akan dipergunakan untuk kepentingan umum. H. Ibrahim, dkk, Siham, dan Sopar Marpaung, Wawancara pribadi, Desember 2009, s/d/ Febuari 2010,

100 Bentuk dan besarnya Ganti kerugian ditetapkan oleh Panitia Pengadaan Tanah tanpa bermusyawarah dengan para pemilik tanah, setelah tanah sudah dikuasai oleh pemerintah. H. Ibrahim, dkk, Siham, Syaiful Akang dan Sopar Marpaung, Wawancara pribadi, Desember 2009 s.d. Febuari 2010.

${ }_{101}$ Pasal 2 Permendagri No.15 Tahun 1975 tentang Ketentuan-Ketentuan Mengenai Tata Cara Pembebasan Tanah, Pasal 8 Kepres No.55 Tahun 1993 tentang Pengadaan Tanah Bagi Pelaksanaan Pembangunan Untuk Kepentingan Umum dan Pasal 7 Perpres No.36 Tahun 2005 tentang Pengadaan Tanah Bagi Pelaksanaan Pembangunan Untuk Kepentingan Umum (sebagaimana yang telah diubah dengan Perpres No.65 Tahun 2006).

${ }_{102}$ Pasal 1 UU No.20 Tahun 1961 tentang Pencabutan Hak-Hak Atas Tanah dan Benda-Benda Yang Ada Di Atasnya. 
kepada Presiden. Tetapi dalam praktik, kedua pilihan itu tidak dilakukan, dengan dalih bahwa Permendagri No. 15 Tahun 1975 yang menjadi dasar tindakannya waktu itu, tidak menentukan adanya kewajiban untuk mengajukan usul pencabutan hak, sementara ganti kerugian telah ditetapkan sesuai dengan ketentuan yang berlaku. Tanah yang telah dikuasai atas dasar instruksi dalam penetapan izin lokasi, tetap dikuasai sekalipun para pemilik tanah menolak bentuk dan besarnya ganti kerugian yang telah ditetapkan.

\section{Penutup}

Berdasarkan uraian di atas, dapat disimpulkan bahwa sengketa pengadaan tanah untuk kepentingan, disebabkan karena : Pertama, hukum pertanahan nasional (UUPA) yang sentralistik, sehingga mendesak keberadaan hukum adat yang masih diikuti oleh masyarakat. Kedua, struktur hukum pelaksana pengadaan tanah yang dikungkung dengan prosedur kerja yang kaku, sehingga bersifat mekanis, dan Ketiga, budaya hukum aparat pelaksana pengadaan tanah terbelenggu oleh tradisi berpikir positivisme hukum, yang memandang hukum sebatas peraturan perundang-undangan dan perintah yang berwenang yang dipahami secara tekstual.

Untuk mencegah atau meminimalisir sengketa, maka ke depan perlu dilakukan perbaikan agar: pertama, secara substantif hukum pertanahan nasional perlu memberikan pengakuan terhadap hukum adat sebagai hukum yang setara dengan peraturan perundang-undangan; kedua, struktur hukum (lembaga) pelaksana pengadaan tanah tidak lagi dikekang secara kaku oleh ketentuan prosedural dan diberi kelonggaran untuk mengambil deskrisi dalam melaksanakan tugasnya, dan ketiga, perlunya perubahan budaya hukum internal pelaksana pengadaan tanah dari budaya legal positivis menuju budaya hukum yang progresif.

\section{Daftar Pustaka}

A.A. Wattimena, Reza, Melampaui Negara Hukum Klasik, Locke-Rousseau-Habermas, Penerbit Kanisius, Yogyakarta, 2007.

Badan Pertanahan Nasional RI, Mandat Politik, Konstitusi dan Hukum Dalam Rangka Mewujudkan Tanah Untuk Keadilan dan Kesejahteraan Rakyat, REFORMA AGRARIA, 2007.

Bakri, Muhammad, Hak Menguasai Tanah Oleh Negara, Paradigma Baru Untuk Reformasi Agraria, Citra Media, Yogyakarta, 2007. 
Damanik, Jayadi, Pembaruan Agraria dan Hak Asasi Petani, Lapera Pustaka, Yogyakarta, 2002.

Darma Putera, Eka, Pancasila Identitas dan Modernitas : Tinjuauan Etnis dan Budaya, Cetkanan Keenam, PT BPK Gunung Mulia, Jakarta, 1997.

Harsono, Boedi, Menuju Penyempurnaan Hukum Tanah Nasional Dalam Hubungannya Dengan Tap MPR-RI No.IX/MPR/2001, Uiverstitas Trisakti, Jakarta, 2002.

Koentjaraningrat, Kebudayaan, Mentalitet dan Pembangunan, Gramedia, Jakarta,1974.

Mahfud, Marbun, Pokok-Pokok Hukum Administrasi Negara, Liberty, Yogyakarta, 1987.

Muslimin, Aspek-Aspek Hukum Otonomi Daerah, Alumni, Bandung, 2006.

Nurjaya, Nyoman, Reorientasi Paradigma Pembangunan Hukum Negara Dalam Masyarakat Multikultural, Perspektif Hukum Progresif, Makalah Seminar Hukum Progresif, Fakultas Hukum Undip bekerja sama dengan Program Doktor Ilmu Hukum Undip dan Fakultas Hukum Universitas Trisakti, Semarang, 15 Desember 2007.

Rahardjo, Satjipto, Membedah Hukum Progresif, PT Kompas Media Nusantara, Jakarta, 2006.

Rasjidi, Lili, Dasar-Dasar Filsafat Hukum, PT. Citra Aditya Bakti, Bandung, 1993.

Ritzer, George - J. Goodman, Douglas, Teori Sosiologi Modern, edisi keenam, alih bahasa oleh Alimandan, Penerbit Kencana, Jakarta, 2007.

Samekto, Adji, Studi Hukum Kritis : Kritik Terhadap Hukum Modern, Badan Penerbit Universitas Diponegoro, Semarang, 2003.

Saptomo Ade, Hukum dan Kearifan Lokal, Revitalisasi Hukum Adat Nusantara, PT. Gramedia Widiasarana Indonesia, Jakarta, 2010.

Sodiki, Achmad, Penataan Kepemilikan Hak Atas Tanah di Daerah Perkebunan Kabupaten Malang, Disertasi, PPs Unair,Surabaya, 1994.

Sumardjono, Marya S.W., Tanah Dalam Perspektif Hak Ekonomi Sosial dan Budaya, Penerbit Buku Kompas, Jakarta, 2009.

Van Dijk R., Pengantar Hukum Adat Indonesia, terjemahan Soehardi, Alumni, Bandung, 1964.

Wignyosoebroto, Soetandyo, Tanah Negara, Tanah Adat yang Dinasionalisasi, Elsam, Jakarta, 1996.

Dua Paradigma Klasik Dalam Percaturan Filsafat Hukum dan Filsafat Sosial untuk Menjelaskan dan Memahami Hakikat Ketertiban Dalam Kehidupan Bermasyarakat Manusia, Bahan Tutorial Dalam Penulisan Thesis dan Disertasi Bidang Ilmu Hukum, Yayasan Dewi Sartika, Semarang, 2005.

Positivisme dan Doktrin Positivisme Dalam Ilmu Hukum dan Kritik Terhadap Doktrin ini, Materi Pelatihan Penulisan Proposal Thesis dan Disertasi bidang Hukum, Yayasan Dewi Sartika, Semarang, 2005. 